\title{
PERBANDINGAN EFEKTIFITAS KOMBINASI TEKNIK MARMET DAN PIJAT OKSITOSIN DENGAN BREAST CARE TERHADAP PRODUKSI ASI PADA IBU POST PARTUM
}

\author{
Ira Titisari, Rahajeng Siti Nur Rahmawati \\ Prodi Kebidanan Kediri Jl.KH.Wakhid Hasyim 64 B Kediri \\ Email: iratitisari@ymail.com
}

\begin{abstract}
Breast milk is the baby food of God's creation that can not be replaced with other foods and beverages. Breast milk is the best baby food and every baby is entitled to breastfeeding. Children exclusively breastfed 14 times more likely to survive in the first six months of life than children who are not breastfed. Start feeding on the first day after birth could reduce newborn mortality risk by 45 percent. Breastfeeding also supports a child's ability to learn and help prevent obesity and chronic diseases later in life. ASI Marmet Technique is issued manually and help milk ejection reflex (Milk Ejection Reflex) has worked for thousands of women in ways not previously owned. Oxytocin massage is massage on the neck, back and along the spine (vertebrae) bone costae until the fifth to sixth. Massage can stimulate the release of oxytocin hormone oxytocin. Oxytocin reflex works spur breast milk. Breast care is the maintenance of the breast is done to facilitate breastfeeding and avoiding difficulties during breastfeeding by doing massage (Welford, 2009). The purpose of this study was to compare the effectiveness of massage techniques Marmet and oxytocin with breast care to the mother's milk production in the post partum. This type of quasi experimental research design The research design used Post Only Design, The population in this study were all post-partum mothers who met the inclusion criteria for the study RSIA Melinda Kediri. A sampling technique that consecutive sampling with a sample of 30 respondents. Data collection is done by dividing into 2 groups: group given Marmet and massage techniques oxytocin and the group given breast care, and to assess milk production using observation sheet milk production. Data analysis technique used was Wilcoxon Mann Whitney U Test. The result showed a p-value arithmetic $(0.870)>$ Alpa $=(0.05)$, which means there is no difference in the combined administration of Marmet and massage techniques and breast care oxytocin on milk production. The conclusion from this study is there is no difference in milk production in mothers postpartum conducted Marmet technique and massage oxytocin with post partum mothers who do breast care. The researchers suggest is that all medical personnel can continue to support the improvement of the quality of obstetric care with attention to maternal postpartum milk production which could have an impact on the process of breastfeeding.
\end{abstract}

Keywords : Marmet Technique, massage oxytocin, breast care, breast milk production, post partum

\section{PENDAHULUAN}

ASI adalah makanan bayi ciptaan Tuhan sehingga tidak dapat digantikan dengan makanan dan minuman yang lain. ASI merupakan makanan bayi yang terbaik dan setiap bayi berhak mendapatkan ASI, dan untuk mempromosikan pemberian ASI, maka Kementerian Kesehatan telah menerbitkan surat keputusan Menteri Kesehatan Nomor: 450 / Menkes / SK / IV / 2004 tentang Pemberian ASI secara eksklusif 
pada bayi di Indonesia. Pada tahun 2012 telah terbit Peraturan Pemerintah (PP) nomor 33 tentang Pemberian ASI Eksklusif dan telah diikuti dengan diterbitkannya 2 (dua) Peraturan Menteri Kesehatan yaitu : Permenkes Nomor 15 Tahun 2013 tentang Tata Cara Penyediaan Fasilitas Khusus Menyusui Dan/Atau Memerah Air Susu Ibu dan Permenkes Nomor 39 Tahun 2013 tentang Susu Formula Bayi dan Produk Bayi Lainnya (Depkes gizi, 2013).

Anak-anak yang mendapat ASI eksklusif 14 kali lebih mungkin untuk bertahan hidup dalam enam bulan pertama kehidupan dibandingkan anak yang tidak disusui. Mulai menyusui pada hari pertama setelah lahir dapat mengurangi risiko kematian baru lahir hingga 45 persen. Menyusui juga mendukung kemampuan seorang anak untuk belajar dan membantu mencegah obesitas dan penyakit kronis di kemudian hari. Penelitian terbaru di Amerika Serikat dan Inggris menunjukkan penghematan besar dalam layanan kesehatan, karena anak yang mendapat ASI jatuh sakit jauh lebih jarang daripada anak yang tidak disusui. Selain manfaat bagi bayi, ibu yang memberikan ASI eksklusif juga berkecenderungan lebih kecil untuk menjadi hamil lagi dalam enam bulan pertama setelah melahirkan, lebih cepat pulih dari persalinan, dan lebih cepat kembali ke berat badan sebelum hamil. Bukti-bukti menunjukkan bahwa mereka mengalami lebih sedikit depresi pascamelahirkan dan juga menurunkan risiko kanker ovarium dan payudara di kemudian hari. Meskipun manfaatmanfaat dari menyusui ini telah didokumentasikan di seluruh dunia, hanya 39 persen anak-anak di bawah enam bulan mendapatkan ASI eksklusif pada tahun 2012. Angka global ini hanya meningkat dengan sangat perlahan selama beberapa dekade terakhir, sebagian karena rendahnya tingkat menyusui di beberapa negara-negara besar, dan kurangnya dukungan untuk ibu menyusui dari lingkungan sekitar (Unicef, 2013).

Data Riset Kesehatan Dasar (Riskedas) 2013 menunjukkan cakupan ASI di Indonesia hanya 42 persen. Angka ini jelas berada di bawah target WHO yang mewajibkan cakupan ASI hingga 50 persen. Angka kelahiran di Indonesia mencapai 4,7 juta per tahun, maka bayi yang memperoleh ASI selama enam bulan hingga dua tahun, tidak mencapai dua juta jiwa. Angka ini menandakan hanya sedikit anak Indonesia yang memperoleh kecukupan nutrisi dari ASI. Padahal ASI berperan penting dalam proses tumbuh kembang fisik dan mental anak dengan dampak jangka panjangnya. Riset Eropa membuktikan pemberian ASI mendukung anak meraih pendidikan lebih tinggi. Hasil senada diperoleh riset yang dilakukan di Denmark pada 3.203 anak. Anak yang menyusu ASI kurang dari satu bulan memiliki tingkat IQ lebih rendah dibanding yang memperoleh ASI hingga 7-9 bulan. ASI juga meningkatkan daya tahan tubuh anak. Berdasarkan riset yang dimuat dalam buletin Lancet pada tahun 2013 diungkapkan, pemberian ASI bisa menekan kematian balita hingga 13 persen (Widiani, 2013).

Penelitian yang dilakukan oleh Siregar (2004) menunjukkan bahwa pemberian ASI eksklusif dipengaruhi oleh berbagai faktor antara lain ASI tidak segera keluar setelah melahirkan / produksi ASI kurang, kesulitan bayi dalam menghisap, keadaan puting susu ibu yang tidak menunjang, ibu bekerja, dan pengaruh/promosi pengganti ASI. Colin dan Scott (2002) dalam penelitiannya yang dilakukan di Australia menjelaskan bahwa 29 persen ibu post partum berhenti menyusui karena produksi ASI berkurang. Sedangkan penelitian yang dilakukan oleh Ahluwia, Morrow, dan Hasia (2005) ditemukan bahwa ibu-ibu berhenti menyusui bayinya pada bulan pertama post partum disebabkan kaena puting lecet, kesulitan dalam melakukan perlekatan yang benar 
serta persepsi mereka tentang ketidakcukupan produksi ASI ibu sehingga tidak dapat memuaskan bayi. Kenyataan di lapangan menunjukkan produksi dan ejeksi ASI yang sedikit pada hari-hari pertama setelah melahirkan menjadi kendala dalam pemberian ASI secara dini. Menurut Cox (2006) disebutkan bahwa ibu yang tidak menyusui bayinya pada hari-hari pertama menyusui disebabkan oleh kecemasan dan ketakutan ibu akan kurangnya produksi ASI serta kurangnya pengetahuan ibu tentang proses menyusui (Mardiyaningsih, 2010).

Teknik marmet yaitu mengeluarkan ASI secara manual dan membantu refleks pengeluaran susu (Milk Ejection Reflex) telah bekerja bagi ribuan ibu dengan cara yang tidak dimiliki sebelumnya. Bahkan ibu menyusui berpengalaman yang telah mampu mengeluarkan ASI diungkapkan akan menghasilkan lebih banyak susu dengan metode ini. Ibu yang sebelumnya telah mampu mengeluarkannya hanya sedikit, atau tidak sama sekali, mendapatkan hasil yang sangat baik dengan teknik ini. Teknik Marmet mengembangkan metode pijat dan stimulasi untuk membantu kunci reflek keluarnya ASI. Keberhasilan dari teknik ini adalah kombinasi dari metode pijat dan pengeluaran ASI. Teknik ini efektif dan tidak menimbulkan masalah (Hormann, 2006). Teknik marmet ini merupakan salah satu cara yang aman yang dapat dilakukan untuk merangsang payudara untuk memproduksi lebih banyak ASI (Nurdiansyah, 2011).

Pijat oksitosin adalah pemijatan pada daerah leher, punggung dan sepanjang tulang belakang (vertebrae) sampai tulang costae kelima sampai keenam. Pijat oksitosin dapat merangsang pengeluaran hormone oksitosin. Oksitosin bekerja memacu refleks pengeluaran ASI. Oksitosin diproduksi oleh kelenjar pituitary posterior. Oksitosin masuk ke dalam aliran darah ibu dan merangsang sel otot di sekeliling alveoli berkontraksi membuat ASI yang telah terkumpul di dalamnya mengalir ke saluran duktus (Depkes RI, 2007).

\section{METODE PENELITIAN}

Populasi dalam penelitian ini adalah Ibu post partum yang ada di RSIA Melinda Kota Kediri pada saat penelitian. Sampel penelitian adalah sebagian ibu post partum yang ada di RSIA Melinda Kota Kediri. Jumlah 30 orang ibu post partum. Teknik sampling yang digunakan dalam penelitian ini adalah Consecutive Sampling yaitu pemilihan sampel dengan menetapkan subjek yang memenuhi kriteria penelitian dimasukkan dalam penelitian sampai kurun waktu tertentu, sehingga jumlah pasien yang diperlukan terpenuhi. (Nursalam, 2011).

\section{Kriteria Sampel}

a. Kriteria Inklusi

1) Bersedia menjadi responden

2) Berdomisili di Kota dan Kabupaten Kediri

b. Kriteria eksklusi

1) Ibu dengan kondisi kesehatan yang tidak memungkinkan untuk menyusui bayinya

2) Ibu yang tidak mau menyusui bayinya

3) Ibu yang bayinya meninggal dunia

4) Ibu yang bayinya mengalami masalah kesehatan sehingga tidak dapat untuk disusui

\section{Variabel Penelitian}

1. Dalam penelitian ini variabel independentnya adalah teknik marmet dan pijat oksitosin dan breast care.

2. Variabel dependentnya adalah produksi ASI.

\section{Analisa Data}

Sebelum menentukan analisa data untuk uji beda maka perlu dilakukan uji normalitas data dengan menggunakan uji Kolmogorov-Smirnov, karena data tidak berdistribusi normal maka digunakan uji Mann-Whitney untuk membandingkan dua sampel independen. Uji ini untuk mengetahui perbedaan antara dua sampel 
independent yaitu kombinasi teknik marmet dan pijat punggung dan breast care dari variabel dependen (produksi ASI). Hasil uji Mann-Whitney dengan melihat nilai $p$ value yakni jika $p<\alpha(0,05)$ maka $\mathrm{H}_{0}$ ditolak yang berarti ada perbedaan dan jika $p \geq \alpha(0,05)$ berarti tidak ada perbedaan produksi ASI antara kombinasi taknik marmet dan pijat punggung dengan breast care..(Sugiono, 2012)

\section{HASIL PENELITIAN}

1. Produksi ASI Pada Ibu Post Partum Yang Dilakukan Pijat Oksitosin dan Marmet

Tabel 4.1 Karakteristik Produksi ASI Pada Ibu Post Partum Yang Dilakukan Pijat Oksitosin dan Marmet

\begin{tabular}{|c|c|c|c|c|}
\hline $\begin{array}{l}\mathrm{N} \\
\text { o. }\end{array}$ & $\begin{array}{l}\text { Produksi } \\
\text { pada hari ke }\end{array}$ & $\begin{array}{l}\text { ASI } \\
-7\end{array}$ & $\begin{array}{l}\text { Fre } \\
\text { kuensi }\end{array}$ & $\begin{array}{l}\text { Persen } \\
\text { tase }(\%)\end{array}$ \\
\hline 1 & $\begin{array}{l}\text { Produksi } \\
\text { banyak }\end{array}$ & ASI & 15 & $100 \%$ \\
\hline 2 & $\begin{array}{l}\text { Produksi } \\
\text { cukup }\end{array}$ & ASI & 0 & $0 \%$ \\
\hline 3 & $\begin{array}{l}\text { Produksi } \\
\text { kurang }\end{array}$ & ASI & 0 & $0 \%$ \\
\hline \multicolumn{3}{|c|}{ Jumlah } & 15 & $100 \%$ \\
\hline
\end{tabular}

Berdasarkan tabel 4.1 dapat diketahui bahwa produksi ASI pada ibu post partum kelompok yang dilakukan pijat oksitosin dan teknik marmet semua 15 orang responden produksi ASInya banyak (100 $\%)$.

2. Produksi ASI Pada Ibu Post Partum Yang Diberi Teknik Marmet

Tabel 4.2 Karakteristik Produksi ASI Pada Ibu Post Partum Yang Dilakukan Breast Care

\begin{tabular}{llccc}
\hline $\mathrm{N}$ & \multicolumn{1}{c}{ Produksi } & ASI & Fre & Persenta \\
$\mathrm{o}$ & pada hari ke-7 & kuensi & se $(\%)$ \\
1 & $\begin{array}{l}\text { Produksi } \\
\text { banyak }\end{array}$ & ASI & 15 & $100 \%$ \\
2 & $\begin{array}{l}\text { Produksi } \\
\text { cukup }\end{array}$ & ASI & 0 & $0 \%$ \\
3 & $\begin{array}{l}\text { Produksi } \\
\text { kurang }\end{array}$ & ASI & 0 & $0 \%$ \\
Jumlah & 13 & $100 \%$ \\
\hline
\end{tabular}

Berdasarkan data dari tabel 4.2 di atas dapat dijelaskan bahwa 15 orang responden atau seluruh responden pada kelompok yang dilakukan Breast Care produksi ASInya banyak (100\%).

Karena distribusi data keduanya tidak normal maka uji t tidak dapat dilakukan, selanjutnya dipilih uji yang sesuai yaitu Wilcoxon Mann Whitney $U$ Test. Berdasarkan uji Wilcoxon Mann Whitney $U$ Test didapatkan hasil p-value $=0,870>$ Alpa 0,05 yang artinya tidak ada perbedaan berat badan dan Frekuensi BAK setelah dilakukan tehnik marmet dan pijat oksitosin dan breast care.

\section{PEMBAHASAN}

1. Produksi ASI Pada Ibu Post Partum Yang Diberi pijat oksitosin dan Teknik Marmet

Berdasarkan hasil penelitian yang dilakukan terhadap ibu post partum yang diberikan teknik marmet dan pijat oksitosin, didapatkan hasil bahwa seluruh responden $(100 \%)$, yaitu sebanyak 15 orang responden mendapatkan produksi ASI yang banyak.

Berdasarkan hasil observasi produksi ASI dilihat dari indikator berat badan bayi, sebagian besar responden (12 orang responden) didapatkan hasil berat badan bayi yang meningkat dari berat badan saat lahir, 3 responden mendapatkan berat badan yang tetap dari berat badan saat lahir. Sedangkan berdasarkan frekuensi buang air kecil, didapatkan seluruh responden frekuensi buang air kecilnya $\geq$ 6-8 kali dalam sehari. Pencapaian dari produksi ASI yang banyak dari seluruh responden ini kemungkinan dapat dipengaruhi oleh pemberian teknik marmet dan pijat oksitosin yang dilakukan oleh peneliti kepada responden 2 kali dalam sehari selama 3 hari.

Menurut Dalzell (2010) dengan melakukan teknik marmet dapat membantu kunci reflek pengeluaran ASI (letdown reflex) yang efektif dalam harihari pertama menyusui, karena tebalnya konsistensi kolostrum dan ketika susu 
matang diproduksi. Teknik Marmet mengembangkan metode pijat dan stimulasi untuk membantu kunci reflek pengeluaran ASI. Keberhasilan dari teknik ini adalah kombinasi dari metode pijat dan pengeluaran ASI yang membantu refleks pengeluaran susu (Milk Ejection Reflex) sehingga ibu menyusui yang sebelumnya hanya mampu mengeluarkan ASI sedikit atau tidak sama sekali, mendapatkan hasil yang sangat baik dengan teknik ini (Hormann, 2006).

Hasil penelitian ini menunjukkan bahwa pemberian teknik marmet dan oksitosin mempengaruhi produksi ASI ibu post partum yang dapat dicapai oleh seluruh responden perlakuan. Pada sebagian ibu post partum dapat terjadi hambatan pengeluaran ASI pada hari pertama setelah persalinan sehingga terjadi perubahan perilaku dalam masyarakat khususnya ibu-ibu yang cenderung menolak menyusui bayinya sendiri dan lebih memilih menggunakan susu formula dengan alasan produksi ASInya hanya sedikit atau tidak keluar sama sekali. Keadaan ini tentu memberikan dampak negatif terhadap status kesehatan, gizi serta tingkat kecerdasan anak. Oleh karena itu, untuk menanggulangi permasalahan tersebut perlu dilakukan upaya preventif dan promotif dalam meningkatkan penggunaan ASI.

Pembentukan air susu sangat dipengaruhi oleh hormon prolaktin dan kontrol laktasi serta penekanan fungsi laktasi. Pada seorang ibu yang menyusui dikenal 2 refleks yang masing-masing berperan sebagai pembentukan dan pengeluaran air susu yaitu refleks prolaktin dan refleks "Let down" (Proverawati, 2010).

Produksi ASI yang rendah bisa diakibatkan dari kurang sering menyusui atau memerah payudara dan memijat payudara. Teknik marmet merupakan kombinasi antara cara memerah ASI dan memijat payudara sehingga reflek keluarnya ASI dapat optimal.
Pengosongan ASI dari sinus laktiferus yang terletak di bawah areola diharapkan akan merangsang pengeluaran hormon prolaktin yang merangsang mammary alveoli untuk memproduksi ASI. Makin banyak ASI dikeluarkan atau dikosongkan dari payudara maka akan semakin banyak ASI akan diproduksi (Astutik, 2014).

Mardiyaningsih (2010) dalam penelitiannya menjelaskan bahwa kombinasi teknik marmet dan pijat oksitosin efektif dalam meningkatkan produksi ASI ibu post seksio sesarea, dimana ibu post seksio sesarea yang mendapatkan intervensi kombinasi teknik marmet dan pijat oksitosin berpeluang 11,5 kali lebih besar produksi ASI nya lancar dibandingkan dengan kelompok kontrol.

Bowles (2011) menyatakan bahwa untuk produksi ASI dan kelancaran pengeluaran ASI memerlukan rangsangan pada otot-otot payudara agar kelenjar payudara bekerja dengan lebih efektif, sehingga otot-otot akan berkontraksi lebih baik dan kontraksi yang baik ini diperlukan dalam proses laktasi. Rangsangan pada otot-otot payudara ini dapat dilakukan dengan pemijatan atau masase payudara salah satunya melalui pemberian teknik marmet ini. Berdasarkan penelitian ini didapatkan bahwa seluruh responden mendapatkan produksi ASI yang cukup. Hal ini dapat disebabkan salah satunya melalui diberikannya rangsangan pada otot-otot payudara agar bekerja lebih efektif melalui pemberian teknik marmet yang dapat merangsang refleks pengaliran / let down refleks yang memicu keluarnya ASI. Sehingga dengan dilakukannya teknik marmet pada ibu post partum dapat membantu meningkatkan kecukupan produksi ASI pada ibu post partum.

2. Produksi ASI Pada Ibu Post Partum Yang Diberi Breast Care

Berdasarkan hasil penelitian yang dilakukan terhadap ibu post partum yang diberikan Breast Care, didapatkan hasil 
bahwa seluruh responden (100\%), yaitu sebanyak 15 orang responden mendapatkan produksi ASI yang banyak.

Berdasarkan hasil observasi produksi ASI dilihat dari indikator berat badan bayi, sebagian besar responden (9 orang responden) didapatkan hasil berat badan bayi yang meningkat dari berat badan saat lahir, 1 responden mendapatkan berat badan yang tetap dari berat badan saat lahir dan 5 responden mendapatkan berat badan yang turun dari berat badan saat lahir tetapi tidak sampai > $10 \%$. Sedangkan berdasarkan frekuensi buang air kecil, didapatkan seluruh responden frekuensi buang air kecilnya $\geq 6$-8 kali dalam sehari. Pencapaian dari produksi ASI yang banyak dari seluruh responden ini kemungkinan dapat dipengaruhi oleh pemberian Breast Care yang dilakukan oleh peneliti kepada responden 2 kali dalam sehari selama 3 hari.

Breast care adalah pemeliharaan payudara yang dilakukan untuk memperlancar ASI dan menghindari kesulitan pada saat menyusui dengan melakukan pemijatan (Welford, 2009).

Perawatan payudara merupakan upaya untuk merangsang sekresi hormone oksitosin untuk menghasilkan ASI sedini mungkin dan memegang peranan penting dalam menghadapi masalah menyusui. Teknik pemijatan dan rangsangan pada putting susu yang dilakukan pada perawatan payudara merupakan latihan semacam efek hisapan bayi sebagai pemicu pengeluaran ASI (Tamboyang, 2001).

Breast care atau perawatan payudara adalah melakukan tindakan untuk menjaga kebersihan payudara, mempertahankan dan menjaga kekencangan payudara, menjaga kehalusan kulit payudara dan menjaga otot dada penyanga payudara. Breast care post partum betujuan untuk memperlancar sirkulasi darah, mencegah tersumbatnya saluran susu sehingga memperlancar pengeluaran ASI serta menjaga payudara agar tetap indah dan kenyal selama masa menyusui dan seterusnya. Payudara yang sehat dan terawat baik, mampu melancarkan produksi ASI. Hal ini membuat proses pemberian ASI menjadi lebih mudah baik bagi ibu maupun bayi.

Mardila Ayu Nilamsari (2014) dalam penelitiannya yang berjudul pengaruh perawatan payudara terhadap kelancaran eskresi ASI pada ibu post partum di Rumah Bersalin Mardi Rahayu Semarang dengan hasil penelitian menunjukkan bahwa sebelum dilakukan perawatan payudara 11 responden (34,4\%) mengalami ekskresi ASI lancar sedangkan 21 responden $(65,6 \%)$ mengalami ekskresi ASI tidak lancar. Setelah dilakukan perawatan payudara hasilnya adalah 24 responden $(75 \%)$ mengalami ekskresi ASI lancar dan 8 responden (25\%) mengalami ekskresi ASI tidak lancar. Penelitian ini menggunakan uji statistik chi square dengan hasil nilai $p \quad 0,018$ dan menunjukkan bahwa nilaip $<0,05$ dengan nilai odds ratio 1,615 sehingga terdapat hubungan perawatan payudara terhadap kelancaran ekskresi ASI dan dengan dilakukan perawatan payudara dapat meningkatkan kelancaran ekskresi ASI 1$2 \mathrm{x}$ lebih besar

3. Perbandingan produksi ASI pada ibu post partum yang dilakukan teknik marmet dan pijat oksitosin dengan ibu post partum yang dilakukan breast care

Berdasarkan hasil analisa dengan menggunakan Wilcoxon Mann Whitney $U$ Test didapatkan hasil p-value $=0,870>$ Alpa 0,05 yang artinya tidak ada perbedaan berat badan dan Frekuensi BAK setelah dilakukan tehnik marmet dan pijat oksitosin dan breast care.

Dari hasil analisa tersebut menunjukkan bahwa tidak ada perbedaan antara kombinasi teknik marmet dan pijat oksitosin dan breast care terhadap produksi ASI. Ketiga teknik tersebut sama-sama efektif dalam meningkatkan produksi ASI pada ibu post partum. 
Hasil penelitian menunjukkan bahwa proporsi ibu pada kelompok yang diberikan teknik marmet dan pijat oksitosin ditemukan paling banyak pada kelompok umur 20-35 tahun dengan responden sebanyak 11 orang $(73,33 \%)$ dan pada kelompok yang diberikan breast care ditemukan semua responden ((15 orang) berada pada kelompok umur 20-35 tahun. Umur merupakan salah satu faktor yang dapat mempengaruhi produksi ASI, ibu yang usianya lebih muda akan lebih banyak memproduksi ASI dibandingkan dengan ibu yang usianya lebih tua (Biancuzzo, 2003). Pendapat lain oleh Pudjiati (2005) bahwa ibu yang berumur 19-25 pada umumnya dapat menghasilkan cukup ASI dibandingkan dengan ibu yang berumur 30 tahun ke atas.

Penelitian yang dilakukan oleh Moore dan Coty (2006) menunjukkan bahwa keberhasilan menyusui tidak ditentukan dari tingkat pendidikan ibu akan tetapi oleh informasi tentang menyusui yang diterima ibu pada saat prenatal. Ibu post partum ternyata membutuhkan pendidikan tentang menyusui pada saat prenatal dan informasi yang diberikan harus konsisten dan realistis. Hasil penelitian ini juga menunjukkan bahwa kelompok yang diberikan teknik marmet dan pijat oksitosin sebagian besar berpendidikan SMA yaitu sebanyak 9 responden $(60 \%)$, 5 orang responden $(33,33 \%)$ berpendidikan Perguruan tinggi sedangkan pada kelompok yang diberikan breast care sebagian besar berpendidikan SMA juga yaitu sebanyak 7 responden $(46,7 \%)$. Tingkat pendidikan seseorang tidak dapat dijadikan pedoman bahwa seseorang akan berhasil pada saat proses menyusui. Akan tetapi informasi yang benar dan diterima tentang proses menyusui sebelumnya akan menentukan keberhasilan proses menyusui. Seseorang yang mempunyai pengetahuan yang memadai akan meningkatkan rasa percaya diri ibu pada saat menyusui. Rasa percaya diri inilah yang akan memperlancar produksi ASI pada masa laktasi, sehingga pendidikan kesehatan tentang menyusui yang diberikan kepada ibu pada saat masa kehamilan dapat membantu ibu untuk mempunyai keyakinan bahwa dia akan berhasil dalam proses menyusui.

Terjadinya penyulit pada saat dilakukan proses laktasi tentunya akan sangat merugikan ibu maupun bayi. Fenomena yang ditemukan di lapangan bahwa produksi ASI menurun pada awal meyusui. Pada umumnya masalah tidak keluar atau terhambatnya produksi ASI dikarenakan dua hal yaitu ASI yang penuh dan saluran ASI yang tersumbat. ASI yang tidak langsung keluar setelah melahirkan adalah hal yang wajar, karena itu ibu post partum harus memancing keluarnya ASI salah satunya melalui teknik marmet. Teknik marmet merangsang reflek keluarnya ASI (let down reflex) yang merangsang reflek pengaliran produksi ASI.

\section{KESIMPULAN}

Berdasarkan hasil penelitian yang dilakukan pada bulan juli sampai September 2015 maka dapat disimpulkan sebagai berikut :

1. Ibu post partum yang diberi teknik marmet dan pijat oksitosin seluruhnya mendapatkan produksi ASI yang banyak.

2. Ibu post partum yang diberi teknik breast care seluruhnya mendapatkan produksi ASI yang banyak.

3. Kelompok ibu post partum yang dilakukan teknik marmet dan pijat oksitosin dan kelompok ibu post partum yang dilakukan breast care sama sama mendapatkan produksi ASI yang banyak.

\section{SARAN}

Berdasarkan hasil penelitian dan kesimpulan yang telah dirumuskam di atas maka perlu disampaikan saran sebagai berikut :

1. Bagi Tempat Penelitian

Dengan adanya hasil penelitian ini diharapkan dapat digunakan sebagai acuan 
untuk meningkatkan mutu pelayanan kebidanan pada ibu hamil dan ibu post partum di RSIA Melinda dengan selalu memperhatikan produksi ASI yang dapat berdampak pada proses pemberian ASI, yaitu dimulai sejak kehamilan yaitu dengan dengan mengajari ibu perawatan payudara (breast care) dan dilanjutkan sampai ibu post partum dengan menggabungkan dengan teknik marmet dan pijat oksitosin.

2. Bagi peneliti

Bagi peneliti, diharapkan dapat lebih meningkatkan pembelajaran di kelas terutama yang berkaitan dengan teknik marmet, pijat oksitosin dan breast care.

\section{DAFTAR PUSTAKA}

Anggraini, Y. 2010. Asuhan Kebidanan Masa Nifas. Yogyakarta: Pustaka Rihama.

Astutik, R. 2014. Payudara dan Laktasi. Jakarta: Salemba Medika.

Biancuzzo, M. 2003. Breastfeeding the newborn: Clinical strategies for nurses. St. Louis: Mosby.

Bobak, I.M., Lowdermilk, D.L., \& Jensen, M.D. (2005). Buku Ajar Keperawatan Maternitas (Maria A Wijayarini \& Peter Anugerah Penerjemah). Jakarta : EGC.

Bowles, B.C., 2011. Breast Massage A "Handy" Multipurpose Tool to Promote Breastfeeding Succes. United States: Lactation Consultan Association.

http://www.clinicallactation.org/sites/ default/files/articlepdf/CL2-

4bowles.pdf. Diakses pada tanggal 13 Februari 2015.

Dalzell, J. 2010. Breastfeeding. United Kingdom: Radcliffe Publishing Ltd.

Depkes gizi. 2013. PEKAN ASI SEDUNIA 2013.

http://www.gizikia.depkes.go.id/archi ves/8659. Diakses pada tanggal 3 Februari 2015

Depkes RI, 2007. Pelatihan Konseling Ibu Menyusui. Depkes RI.
Derni, M. 2007. Serba-serbi Menyusui. Depok: WaRM Publishing

Dewi, V. 2012. Asuhan Kebidanan pada Ibu Nifas. Jakarta: Salemba Medika.

Gibney, M.J. 2008. Gizi kesehatan Masyarakat. Terjemahan oleh Andry Hartono,dkk. Jakarta: EGC.

Hidayat, AAA. 2007. Metode Penelitian Keperawatan dan Teknik Analisis Data. Jakarta: Salemba Medika.

Hormann, E. 2006. Breastfeeding an Adopted Baby and Relactation. United States of America: La Leche League International.

Huliana, M, 2003. Perawatan Ibu Pasca Melahirkan. Jakarta : Puspa Swara

Kristiyansari, W. 2009. ASI, Menyusui \& Sadari. Yogyakarta: Muha Medika.

La Leche League International. 27 Oktober 2003. Manual Expression of Breast Milk Marmet Technique. http://1llrochester.weebly.com/upload s/7/9/5/4/795404/marmet_technique_t earoff.pdf. Diakses pada tsnggal 13 Februari 2015.

Mardiyaningsih, E. 2010. Efektifitas kombinasi teknik marmet dan pijat oksitosin terhadap Produksi asi ibu post seksio di rumah sakit wilayah jawa tengah. Depok: FIK UI. http://lontar.ui.ac.id/file?file=digital/2 0282666-

T+Eko+Mardiyaningisih.pdf. Diakses pada tanggal 13 Februari 2015.

Maryunani, A. 2012. Inisiasi Menyusui Dini, ASI Eksklusif dan Manajemen Laktasi. Jakarta: Trans Info Medika.

Moore, E. R., Coty, M.B. 2006. Prenatal and postpartum focus groups with primiparas: breastfeeding attitudes, support, barriers, self-efficacy, and intention. Journal Pediatrics Health Care 20, 3546.

Nilamsari,M.A. 2014. Pengaruh Perawatan Payudara Terhadap Kelancaran Ekskresi ASI Pada Ibu Post Partum di Rumah Bersalin Mardi Rahayu Semarang. http://pmb.stikestelogorejo.ac.id/e- 
journal/index.php/ilmukeperawatan/ar ticle/viewFile/271/296. Diakses pada tanggal 11 November 2015.

Notoatmodjo, S. 2010. Metodologi Penelitian Kesehatan. Jakarta: Rineka Cipta

Nugroho, T. 2011. ASI dan Tumor Payudara. Yogyakarta: Nuha Medika.

Nurdiansyah, N. 2011. Buku Pintar Ibu dan Bayi. Jakarta: Bukune.

Nursalam. 2011. Konsep dan Penerapan Metodologi Penelitian Ilmu Keperawatan Pedoman Skripsi, Tesis, dan Instrume Penelitian keperawatan. Jakarta: Salemba Medika.

Prasetyono, D. 2009. Buku Pintar ASI eksklusif pengenalan, praktik, dan pemanfaatannya. Jogjakarta: Diva Press.

Proverawati, A. 2010. Kapita Selekta ASI dan Menyusui. Yogyakarta: Nuha Medika.

Pudjiadi. 2005. Ilmu gizi klinis pada anak Edisi 4. Jakarta: FK UI.

Rahayu, D. 2012. Faktor - Faktor yang Mempengaruhi Produksi ASI pada Ibu Nifas.http://stikesbaptis.ac.id/utama /index.php?option=com docman\&ta sk=doc download\&gid=17\&ltemid=1 11. Diakses tanggal 18 Juli 2015.

Ramaiah, S. 2006. ASI dan Menyusui. Jakarta: Buana Ilmu Populer.

Saleha, S. 2009. Asuhan Kebidanan pada Masa Nifas. Jakarta: Salemba Medika.

Sears, W. 2007. The Baby Book, Everything You Need to Know About Your Baby From Birth to Age Two. Terjemahan oleh Dwi karyani, dkk. Jakarta: SERAMBI ILMU SEMESTA.

Setiawandari. 2013. Perbedaan Pengaruh Teknik Marmet Dengan Pijat Oksitosin Terhadap Produksi ASI Ibu Postpartum Di Rumah Sakit Ibu Dan Anak Ibi Surabaya. http://s2mkk.pasca.uns.ac.id/?m=20 1404\&paged=5. Diakses tanggal 18 Februari 2015.

Soetjiningsih. 2005. ASI, Petunjuk Untuk

Tenaga Kesehatan. Jakarta : EGC

Sugiyono. 2012. Statistika Untuk

Penelitian. Bandung: Alfabeta.

Suryawati, C. 2007. Faktor Sosial Budaya dalam Praktik Perawatan Kehamilan, Persalinan, dan Pasca Persalinan di Kecamatan Bangsri Kabupaten Jepara.

http://ejournal.undip.ac.id/index.php/j pki/article/view/2800. Diakses tanggal 18 Februari 2015.

Unicef Indonesia. 2013. ASI adalah penyelamat hidup paling murah dan efektif di dunia. http://www.unicef.org/indonesia/id/m edia 21270.html. Diakses pada tanggal 3 februari 2015.

Weiss, E. 2006. The better Way to Breastfeed. LCCE.CLC.

Widiani, R. 2013. Cakupan ASI 42 Persen, Ibu Menyusui Butuh Dukungan. http://health.kompas.com/read/2013/1 2/21/0917496/Cakupan.ASI.42.Perse n.Ibu.Menyusui.Butuh.Dukungan.

Diakses pada tanggal 3 Februari 2015.

Widuri, H. 2013. Cara Mengelola ASI Eksklusif Bagi Ibu Bekerja. Yogyakarta: Gosyen Publishing.

Wiji, R.N. 2013. ASI dan Panduan Ibu Menyusui. Yogyakarta: Nuha Medika 